\title{
ENTREPRENEURSHIP AND INNOVATION HUB AT A PRIVATE UNIVERSITY IN RIO GRANDE DO SUL
}

\author{
EMPREENDEDORISMO E INOVAÇÃO EM UMA \\ UNIVERSIDADE PRIVADA DO RIO GRANDE DO SUL
}

\section{Luis Felipe Maldaner1, Alexandre Pereira2², Daniela Carolina Eckert³}

Recebido em: 06 de maio de 2017

Aprovado em: 28 de junho de 2017

Sistema de Avaliação: Double Blind Review

RPR | a. 14 | v. 2 | p. 147-164 | jul./dez. 2017

\begin{abstract}
The proposed hub of Academic Activities in the areas of Innovation and Entrepreneurship for teaching undergraduate students originated in the strategic project of the University entitled "Tecnosinos Project - São Leopoldo Tech Park". The main objective of this project is to make Unisinos University a technology-fostering agent, conducting applied research in Entrepreneurship and Innovation. This paper will discuss the importance of the entrepreneurship education and the successful partnership between Unisinos and Tecnosinos Tech Park on an innovative program that has positively influenced a large number of students since 2011, fostering the birth of new startups. The methodology of this article is related to a case study originated from a qualitative applied research with secondary data collection from register and from academic curricula. Additionally this work took primary data collection through interview with professors and with Unitec manager, who is responsible of this project from Tecnosinos side. Results from this study shows increasing number of students participants of different kind of activities. A part from education, some activities focused on entrepreneurship promotion, such as Warm up, Roser Award and Innomarathon, that resulted in more than six projects that became startups at Unitec Incubator.
\end{abstract}

Keywords: Entrepreneurship. Innovation. Hub. Connection. Education.

\section{RESUMO}

A proposta de criação do eixo de atividades acadêmicas nas áreas de Inovação e Empreendedorismo, para ensinar esses temas aos alunos da Graduação, originou-se no projeto estratégico da Universidade denominado "Projeto Tecnosinos - Parque Tecnológico São Leopoldo". O principal objetivo desse projeto é promover a Unisinos como um agente de fomento ao desenvolvimento tecnológico, conduzindo pesquisa aplicada em Inovação e Empreendedorismo. Este artigo discute a importância da educação empreendedora e a parceria de sucesso entre a Unisinos e o Tecnosinos - Parque Tecnológico de São Leopoldo, como um programa inovador que influencia positivamente um grande número de estudantes, desde 2011, promovendo o surgimento de novas startups. Este artigo é um estudo de caso originado de uma pesquisa qualitativa baseada em dados secundários obtidos dos registros do Tecnosinos e de análise das ementas das disciplinas de empreendedorismo. Adicionalmente foram feitas algumas entrevistas com professores do eixo e com o gerente da Incubadora Unitec, responsável por esse projeto da parte do Tecnosinos. Os resultados desse estudo mostram que há um número crescente de estudantes participantes em diferentes atividades relacionados ao eixo. Além da educação empreendedora, algumas atividades estão focadas em promover o empreendedorismo, tais como Warm

\footnotetext{
${ }^{1}$ Doutor em Estudos Latino Americanos pela Hankok University of Foreign Studies (Seul/Coréia do Sul). Professor na Universidade do Vale do Rio dos Sinos (São Leopoldo/Brasil). E-mail: luisfelipe5609@ gmail.com.

${ }^{2}$ Mestre em Administração pela Universidade do Vale do Rio dos Sinos (São Leopoldo/Brasil). Professor na Universidade do Vale do Rio dos Sinos (São Leopoldo/Brasil). E-mail: alexanpereira@unisinos.br.

3 Mestranda em Administração na Universidade do Vale do Rio dos Sinos (São Leopoldo/Brasil). E-mail: danielaeckert@feevale.br.
} 
up, o Prêmio Roser e o Innomarathon que resultaram em mais de seis projetos que se tornaram startups na Incubadora Unitec.

Palavras-chave: Empreendedorismo. Inovação. Eixo. Conexões. Educação.

\section{INTRODUCTION}

Unisinos University has been encouraging, in addition to the strong tradition of Christian social humanism, the development of technology-based research to contribute in real society problem solving and in order to align the strategic proposals of the region to the Science and Technology sector. The construction of the Entrepreneurship and Innovation Hub (E\&I Hub) started during the year 2010, based on discussions held by a group of Unisinos teachers of undergraduate and graduate specialists on the subject. Such discussions were fundamental to: (a) define the theoretical assumptions of an academic background in Entrepreneurship and Innovation; (b) verify what Unisinos already ministered at graduation in these areas; and (c) identify and briefly describe the experiences of some national and international universities on these two issues. Still in 2010, the Entrepreneurship and Innovation Hub (E \& I HUB) was created by Resolution No. 22/2010 of the Committee of Undergraduation Program to meet the dimensions of teaching Innovation and Entrepreneurship at undergraduation through the organization of three academic activities at that time.

From 2015, the E \& I HUB has evolved and grown becoming a set of four academic activities (see Figure 1), plus two activities offered in English, so that students of all undergraduate university courses may have a broad comprehension combined with the practice of Innovation and Entrepreneurship. The goal is to enrich the curriculum of all undergraduate programs and give the students the opportunity to discuss and practice Entrepreneurship and Innovation, enabling students to have a preeminent performance in the labor market. Several academic activities that are part of the E \& I HUB are ministered at Unitec, the incubator of Unisinos, located at Tecnosinos, thus the students have a close experience with the tech park environment.

The fact that an expressive amount of E \& I HUB classes is ministered at the incubator is the major factor of its success as a program. The incubated companies are invited to talk about their cases and help the students with their activities. In addition to that, all the teachers of the E \& I HUB spend from 2 to 3 hours per week at the Unitec, where they are available for the companies that are in process of incubation. Those hours are of great value, not only for the companies that can consult with the teachers on subjects of their field of expertise, but also for the teachers, that have a close relationship with the companies, their struggles and accomplishments. This interaction makes this academic activity very dynamic and interesting for the students, and have increased their knowledge regarding entrepreneurship and innovation.

There are four academic activities part of the E \& I HUB: (I) Entrepreneurship and Innovation: Concepts and Practice (Portuguese and English); (II) Organizational Entrepreneurship and Innovation (Portuguese and English); (III) Entrepreneurship and Innovation Workshop; and (IV) Entrepreneurship and Innovation Management. The activities I and II are specific to the bachelor's and are also offered in English, as a result of the university's internationalization movement. Activity III is specific to the technological graduations and activity IV is optional for both. The following tables provide a brief description of the skills covered in each. 
Figure 1 - E \& I HUB Academic Activities

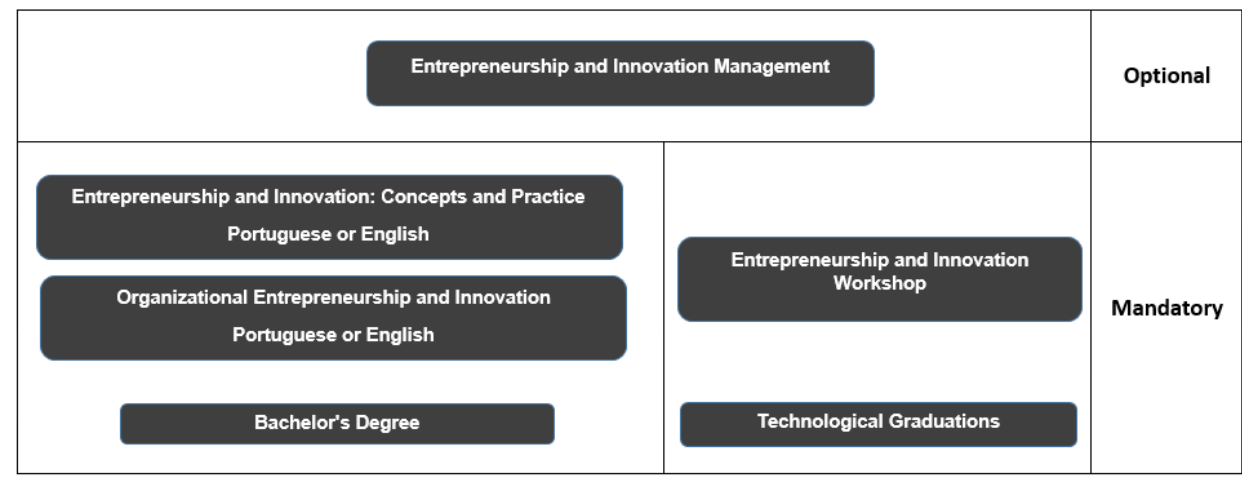

Source: Unisinos, 2016

This article will go more deeply on that academic curriculum in the follow sections that will include figures of students' attendance in each academic activity. In the section 2 this work will provide a literature review that discuss themes related to Entrepreneurship and Innovation.

\section{LITERATURE REVIEW}

In this section, it will be discussed two special points related to entrepreneurship. The first one is a historical point of view regarding entrepreneurship spirits in Latin American countries. It is possible to say that Latin American people have a different behavior in terms of entrepreneurship comparing American people, taking for example all the initiatives in Silicon Valley.

The second point in this section is related to innovation and competitiveness, as per the World Economic Forum report. Innovation is a fundamental pillar to countries' development. The global market is extremely competitive and the companies must be prepared for that. The focus of this paper is related to entrepreneurship education, which is the started point in order to increase the number of companies in the market. Nowadays, in this knowledge era, many startup companies are born global. Technology and innovation are spreading very fast through social media. Thus, it is a key of success to think global.

\subsection{ENTREPRENEURSHIP SPIRIT}

There are some key points that come out from the historical perspective of the Latin American society formation. First, the people' mind set in most of the Latin American countries do not have the entrepreneurship spirits like in U.S. for example. Second, in those countries there is not the willing to invest in new business that involve some risk. Third, in the absent of the entrepreneurships spirits, the government have had to take the position as the main investor in new areas such as steel, for example. Gwynne (2004) refers on that:

In order for South American countries to achieve a more mature industrial structure, the political consensus was that governments should actively intervene not only through the elaboration of industrial policy but also through the creation of stateowned development corporations. Governments drew up strategic plans for industrial sectors and facilitated investment in key industries, such as steel, where it was thought that national private investors might be unwilling to venture (GWYNNE, 2004, p. 43).

At the same time, even the existing entrepreneurs were not willing to face the concurrency of the international market. "Paradoxically, the resulting rejection of the neoliberal agenda has found support in Latin America among quite heterogeneous political and social groups; these include the left, 
certain religious groups, some nationalist sector and some entrepreneurial circles afraid of free-market policies and especially of foreign competition (SILVA, 2004, p. 158)".

On the other hand, the entrepreneurs complain against the high level of bureaucracy to establish a new business. "One popular idea, for example, is the repeal of regulations and policies which obstruct entrepreneurship without serving any legitimate public regulatory purpose (CHANT, 2004, p. 299)". In some sense, it sounds like an excuse to be accommodate in the currently status quo, but that bureaucracy really exist in Latin America, another legacy from the colonization period. Some authors referred that Latin America had not passed through the Weberian process of bureaucracy improvement that Max Webber described in Europe in the early 1900s.

Beside the entrepreneurial spirit was not well developed in Latin America, at the same time the education system does not provide opportunities for those who want to have lessons about it or develop their skill and abilities to become an entrepreneur. Historically, neither the schools nor the colleges are oriented to business education. Almost all of the graduate and post-graduate courses have an academic orientation rather than business orientation.

Another point that is important to mention is that on those Latin American countries, where the European immigration was more effective, the entrepreneurial spirit appear more often. In South of Brazil, the Germany and Italian immigrants were the main entrepreneurs in different sectors, as for example, shoes factories in Sinos Valley by the Germany immigrants and metallurgy sector in Rio Grande do Sul, by the Italian immigrants.

Entrepreneurship is a word that is spreading worldwide as a new concept of how to start a new business. However, it is not new in terms of the existence people who started a new business. For example, in the Sinos Valley region, from the beginning of incoming immigrants from Germany (1824), the entrepreneurs from those times started several small business, such as new factories, especially shoemakers and metal mechanic sector.

Considering some historical facts, looking back to the industrial revolution in Great Britain, it was a prosper period of inventions, especially from Scottish people. Some of those inventors were simple workers that developed new machineries based on their experience and need. The Industrial Revolution was a fundamental change in the way to produce goods, from human labor to machines (HOBSBAWM, 1996). Anyone taught them how to become an entrepreneur. It was an evolution process that brought consistent changes in the ways of production.

In this regard, it is possible to infer that entrepreneurship cannot be taught. According to Schumpeter (1942: 1975, p.132): "The entrepreneurial function does not essentially consist in either inventing anything or otherwise creating the conditions which the enterprise exploits. It consist in getting things done". In some sense, it is possible to say that not everyone will become an entrepreneur.

Oliveira (2014) defines entrepreneurship as an evolution process of capacities, abilities and professional attitudes to enhance results of enterprises and to consolidate new strategic relevant projects. In contrast, Degen (2009) refers to the entrepreneur as a person who has the business vision and make all efforts to realize that vision. In the same way of thinking, Kuratko \& Hodgetss (2004) describe entrepreneurship as a dynamic process of vision, change, and creation. For them it requires an application of energy and passion towards the creation and implementation of new ideas and creative solutions. They added that this implementation imply some risk-taken, and the ability to prepare a venture team. At the end, it is necessary resources and fundamental skills to build solid business plan. From other perspective, entrepreneurs have to have the capacity to see opportunities where normally people do not see. 
As it is mention above, entrepreneurship is not a discipline that can be taught, but there are many different ways to instigate and to develop skills and abilities in order to incentive people to start new business. According to Lima et al. (2015),

[...]the search for empirical evidence concerning the effects of entrepreneurship education is still necessary. Von Graevenitz, Harhoff, and Weber (2010) state that the work in the field is still weak. The studies on the effects of entrepreneurship education are somewhat inconclusive. There are two main streams of research results. The first and predominant one indicates that entrepreneurship education magnifies the development of entrepreneurial intention and belief of being capable of successfully performing the roles and tasks of an entrepreneur (entrepreneurial self-efficacy; according to Chen, Greene, and Crick 1998). The second one, however, demonstrates indifference (lack of effects) or diminishing effects of entrepreneurship education, and initiatives related to it, on entrepreneurial intention and perceived competencies for entrepreneurship (LIMA et al., 2015, p. 1034).

In terms of entrepreneurship education, the real problem is to identify how it works and what are the main practical results of it in the long run. There is no meaning in spending a lot of effort teaching these discipline whether it is not possible to see any results in terms of new business setting up in the nearby environment. It seems more significant to a University involved in this kind of effort if there is a Tech Park connected in which students can take into practice their ideas or projects, and opening their own business. According to Rideout and Gray (2013, p. 329) "technopreneurial course content requires unique curricular aspects like technology product ideation, new business model identification, intellectual property protection, team-building, prototyping, networking and strategic partnerships, and venture/angel capitalization". However, these disciplines are not a guarantee that the students will become entrepreneurs. It is necessary structures to support them in their venture, as an incubator for example, and incentives such as business project awards. Additionally seed capital is very welcome in the environmental. Another important point is risk-taken. Sanchez (2013) mentions "that this is a personality trait that determines the tendency and willingness of an individual to take on risk. This trait has been related to entrepreneurship because entrepreneurial activity by definition involves assuming some type of risk" (SANCHEZ, 2013, p. 451).

\subsection{INNOVATION AND COMPETITIVENESS}

The World Economic Forum published "The Global Competitiveness Report 2010-2011, describing the 12 pillars of competitiveness with comprehensive view of this theme. "Today's stilldifficult economic environment requires not losing sight of long-term competitiveness fundamentals amid short-term urgencies [...] "Competitive economies are those that have in place factors driving the productivity enhancements on which their present and future prosperity is built" (SALA-I-MARTIN et al., p. 3).

At the same time, it is important to ask: what is competitiveness? It is possible to borrow the definition from the dictionary, which is: "the ability of a company, country, or a product to compete with others [...] the desire to be more successful than other people (LONGMAN DICTIONARY, p. 312)". It is possible, simply saying, that in terms of business, competitiveness is to produce better than others do. "We define competitiveness as the set of institutions, policies, and factors that determine the level of productivity of a country. The level of productivity, in turn, sets the sustainable level of prosperity that can be earned by an economy" (SALA-I-MARTIN et al., 2010, p. 4).

According to Schumpeter (1942:1975), innovation can be defined not only as an invention, but also to develop a new source of material, or a new market: 
We have seen that the function of entrepreneurs is to reform or to revolutionize the pattern of production by exploiting an invention or, more generally, an untried technological possibility for producing a new commodity or producing an old one in a new way, by opening up a new source of supply of materials or a new outlet for products, by reorganizing an industry and so on (SHUMPETER, 1942:1975, p.132).

Innovation does not occur by some fortuity, nor is it isolated. There are conjunctions of actions and agents that interact among themselves to the affectivity of the change process, which is, in the Schumpeterian vision, the new element responsible for the trajectory alteration of the economic circle flow. "The National System of Innovation is an institutional construction, a product from a planned and conscious action, which impulses the technology progress in complexes capitalists economies" (ALBUQUERQUE, 1996, p.57).

According to Dahlman \& Frischtak (1993), the System of Innovation can be defined as a relationship and interchange network among several institutions and economic agents that work in new technologies. In the emerging economies, the system includes the new technologies transfers, importation of new equipment and even Foreign Direct Investment (FDI). Also public and private investment in research, development and diffusion of technology innovations.

There are diverse systems in accordance of its own development stage in which each country is. According to Albuquerque (1996), there are three different categories of innovation systems, as shown in figure 2:

Figure 2 - Innovation Systems categories

\begin{tabular}{|c|c|c|}
\hline 1st category & $\begin{array}{c}\text { Developed countries, mature systems, close to the } \\
\text { technological frontier }\end{array}$ & $\begin{array}{c}\text { United States, Japan, Germany, France } \\
\text { and Italy }\end{array}$ \\
\hline 2nd category & $\begin{array}{c}\text { Countries with technological dynamics concentrated in } \\
\text { diffusion; small in terms of territory and close to developed } \\
\text { countries }\end{array}$ & $\begin{array}{c}\text { Sweden, Denmark, Netherlands, } \\
\text { Switzerland, South Korea and Taiwan. }\end{array}$ \\
\hline 3rd category & $\begin{array}{c}\text { Countries with developed C\&T, but who have not completed } \\
\text { their own system of innovation }\end{array}$ & Brazil, Argentine, Mexico and India. \\
\hline
\end{tabular}

\section{Source: Albuquerque (1996)}

Dutrenit (1994) considers the National System of Innovation as a conjunction of agents, institutions, articulations and social practices associated with innovative activity inside a country. To the author, the innovative dynamic depends more on the learning process than on the resources. It is inside the national systems where the learning process occurs which allows to reproduce and to feedback to the individual and collective memory. This system generate the conditions to have the interactions between agents and organizations, in a kind of moto-continuous in which the process of innovation learning is developed. It is important to say that, to the author, the technology accumulation happens inside the company and the company external ambience would be an ideal space where the positive dynamic conditions to generate the technology innovation.

According to the OECD Oslo Manual (2004), innovation results from a growing complex of local, national and global interactions among individuals, firms and other knowledge institutions. Governments also have a strong influence on the innovation process through the financing of public organizations, which are involved in knowledge generation, such universities, researches institutions and through the financing incentives to all agents involved in the innovation system.

Knowledge has an important role in the economic development, and the innovation is in the center of the economy. According to the OECD, the innovation is systemic and complex phenomena. 
This systemic concept changes a focus of the policy, setting more emphasis on the institutional interactions. Thus, "to this conjunct of institutions and knowledge flow was given the name National System of Innovation" (OECD, 2004, p. 17), expression that was originally created by Freeman (1990), in 1987, highlighting the concept of national, and the relevancy of the articulation among all agents, as such government, universities, research institutes and enterprises.

The strategic importance of knowledge is shown by the growing investments in $\mathrm{R} \& \mathrm{D}$, education and training. According to the OECD (2002), the policies structure must emphasize the innovation capacity and the knowledge generation in the affiliate countries. Thus, "the technology changes result from innovative activity, which includes immaterial investments, as in R\&D” (OECD, 2004, p. 31).

Figure 3 - Factors map of the innovation field

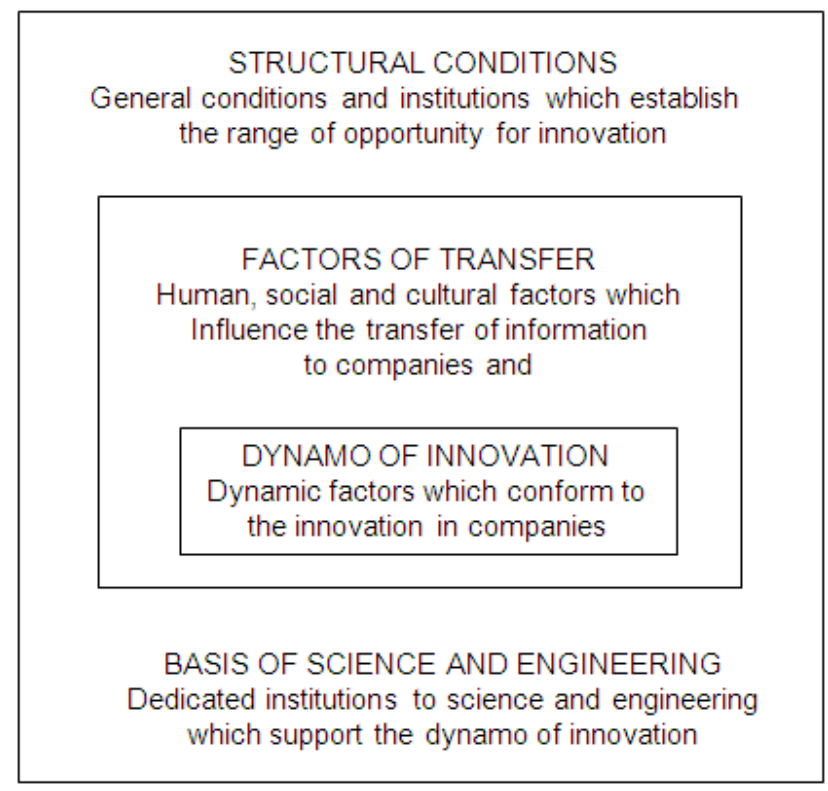

Source: OECD (2004)

The ambient analysis can be divided into two main aspects. In the macro level, there are some evidences that the innovation is a dominant factor in the economic national growth and international trade standards. In the micro level, R\&D is a seed of the larger firms' capacity to absorb and work with the new knowledge.

In addition to the intra-organizational ambience mentioned above, there is an external ambient where the company is, and the structural factors that provide a favorable conjunct to the innovation. According to the OECD Oslo Manual, the conceptual structure of these factors can be reported in a map that define four general dominions, forming the innovation policy field, as shown in the figure 3 . This conjunct of inter-related factors describes the generic form as the national system of innovation is shown. It seems that there is a certain hierarchy among them (figure 3), as the innovation dynamo would be the minor cell on this map. It means that the innovation occurs in the firm. The structural conditions would be the macro-ambient, where the rules are fixed, and it is possible to divide into the following aspects:
a) Education system;
b) Communications infra-structure;
c) Financing system;
d) Macro-economic and legal context;
e) Market conditions;
f) Industry structure; 
g) Science and Technology infrastructure.

According to OECD Oslo Manual (2004), the scientific knowledge and the engineer capacity are fundamental conditions to the innovation. Thus, the interaction among universities, research institutes and firms is the most important aspect for the innovation growing in the economic ambient. Perez (2001) mentions that, in case of developing countries, there are no growing without effort in this area. "There is no magic formula to conquest the development without the public dominions of technology, and without people having the economic and technical knowledge" (PEREZ, 2001, p. 125).

Still according to OECD Oslo Manual (2004), there are some elements in the national base of science and engineer as below:

- Specialized technical training;

- Universities and research institutes;

- The support mechanisms to the basic research;

- The R\&D (Research and Development) public activities - financial programs and institutions in areas such as health, environment and national defense;

- R\&D strategic activities - financing programs and institutions which are in R\&D precompetitiveness or in generic technologies;

- Support to a non-owned innovation - financing programs and institutions that are researching

in difficulty areas where firms cannot obtain sufficient benefits from their own research.

This chapter was a tentative to summarize the literature related to the two main topic of this article, which are entrepreneurship and innovation. It was a very important part of this work in order to have an overview of those subjects and to realize how those themes are getting an academic interesting worldwide.

In the next section it will describe the methodology based on this study was developed.

\section{METHODOLOGY}

This work is a result from several activities related to the connection of Tecnosinos Tech Park and academic initiatives of Unisinos in order to register a long way of practices and achievements that came out from that. In this sense, this article can be considered a case study of the Entrepreneurship and Innovation Hub.

In this regard, this is a case study originated from a qualitative applied research with secondary data collection from register and from academic curricula. Additionally this work took primary data collection through interview with professors and with Unitec manager, who is responsible of this project from Tecnosinos side. According to Prodanov and Freitas (2013), qualitative studies have the objective to get a depth understanding of a phenomena or case. This is the main goal of this article regarding the Entrepreneurship and Innovation Hub between Tecnosinos Tech Park and Unisinos University.

The first step was to have an understanding of the Entrepreneurship disciplines, which are in the academic curricula and have the objective to disseminate the concepts and practices in order to become an entrepreneur. Thus, those curricula were exanimated and discussed with respective professors in order to clarify all activities.

The second part of this work was to have the same understanding of those activities developed in Unitec, which is the Unisinos incubator installed inside Tecnosinos that are connected with E \& I Hub. In order to get information, the manager of Unitec was the interviewed person.

After to absorb the correct understanding of the activities in both parts the follow work was to see how those activities were run. The authors of this article participate as an assistant of an activity 
inside Unitec incubator, such as a Canvas business plan. This participation offered the opportunity to describe them exactly as they happen.

Additionally the authors could have a broadly overview of all activities that are done in Unitec related to Unisisnos students and with students from other high schools. It was possible to collect all data that was in Unitec register that shown a long run of several kinds of activities. It is important to mention that Unitec has agreements with more than 30 high schools in the region. Every year students from those schools visit Unitec/Tecnosinos. All those visits are adequately register in an appropriate document, which includes students' identifications, e-mail address and signature. It is the same for University students' registration. All documentation are available and it is possible to check any time.

In the next section it will be described the main activities focus on entrepreneurship in order to motivate students to think over this possibility

\section{ACTIVITIES RELATED TO ENTREPRENEURSHIP HUB}

In this section, four activities, in which students take part, will be described. Those activities are inside the academic curricula as the disciplines that are transversal in all under graduation courses. In most of them, such as administration, economy or accounting, they are mandatory. In other courses, they are optative. However, the experience of Unisinos shown that almost one third of all undergraduate students take at least one of those four activities.

\subsection{ENTREPRENEURSHIP AND INNOVATION: CONCEPTS AND PRACTICE}

The content of this activity is related to the importance of discussing entrepreneurship and innovation while training professionals in the contemporary society. The main goal is to study concepts and understandings regarding entrepreneurship and innovation thinking that there are some personal characteristics of entrepreneurship that must understand. Normally youth students are familiar with some innovations, like app for mobiles and all sort of social media. However they are not familiar with the concepts of innovation, neither what really is innovation, whether it is disruptive or incremental. Thus, to study some academic concepts is relevant for them, especially if they will become an entrepreneur.

Another important theme discussing in this activity is also related to personal characteristic such as creativity, leadership and interpersonal skills. Those characteristics are not common for everyone. Some people prefer work as an employee lifelong. It is personal. Some people want to take their future in their own hands, and take the risk to open their own enterprise. Even though, it is possible to see different types of entrepreneurs, such as intrapreneur or corporate entrepreneur, the succession entrepreneur and social entrepreneur.

The final subject of this discipline is to understand the entrepreneurial process and the identification and analysis of opportunities. The process must be explained to the students because it is not simple to decide to open a startup. They need to know that there is a way that must be followed. However, the main point here is to clarify how the students can see an opportunity. It means to open their eyes for a new vision that can take them to a new way of life.

Regarding attendance of this discipline it is possible to see on figure 4, that the number of students in this discipline is being increasing from around 600 in 2011 to more than 1.200 in 2015. More than double students in 5 years. It means that this was a successful initiative. 
Figure 4 - Attendance of students in Activity 1

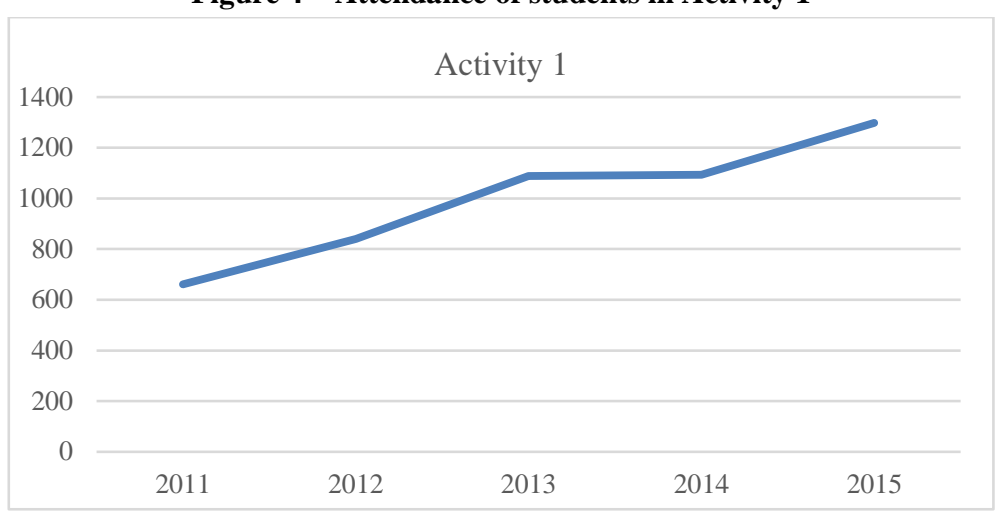

Source: UNISINOS, academic register, 2016

\subsection{ORGANIZATIONAL ENTREPRENEURSHIP AND INNOVATION}

The main competence worked in this academic activity is related to innovation and entrepreneurship in businesses and organizations in general. Students can take this discipline only after they have taken the activity one. It means that they have already studied all basic concepts of entrepreneurship and innovation. Thus, they are able and prepared to learn how to open an innovative startup.

Another subject of this discipline is to study the characteristics of Brazilian companies and the national environment set to innovation and entrepreneurship. In some Brazilian traditional industrial sector, companies are not so innovative. However, they continue to be in the market as a strong player, because their market is not so competitive. They do not need to be up to date. The students must understand that this is not what normally occurs in a competitive market. Other companies are in the opposite side, a competitive market and must to be up to date in terms of innovation. They need new ideas. However, those new ideas or projects must go into practice. This is the starting point for the students to work in this activity.

The final part of this discipline is to implement a processes and stages for creating a new venture. For that, the students must know the tools necessary for the practice of entrepreneurship and innovation, such as development and analysis of scenarios, mapping and analysis of external and internal organizational environments; and the process of building and understanding of a Business Model (Business Model Generation) and a Business Plan. Only to know is not enough. They must practice it. Therefore, at the end of the semester, students have to present their business plan of an innovative company as a mandatory work to get the grade and successfully complete this discipline.

The success of this course among students can be seen on figure 5. From 2011 to 2015, the attendance is increasing more than double. This graphic shows that the attendance of the activity 2 is increasing more than activity 1 in the same period. It means that students are interesting to learn how to prepare a business plan. It seems that Unisinos University is in the right way in terms of entrepreneurship education. 
Figure 5 - Students Attendance in Activity 2 - 2011 to 2015.

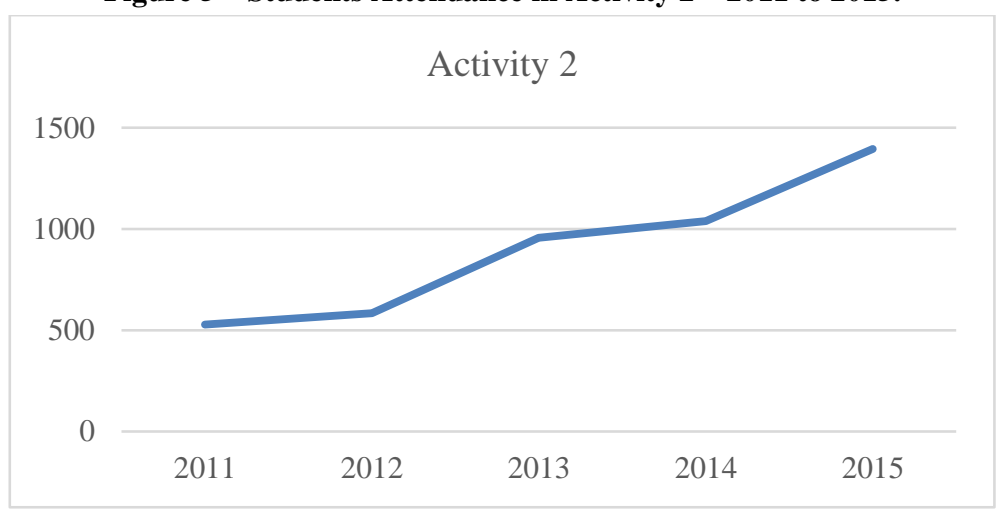

Source: Unisinos, academic register, 2016

\subsection{ENTREPRENEURSHIP AND INNOVATION WORKSHOP}

Comparing this activity with activities I and II, the attendance shown in figure 6 , seems that students are interested in its subject, which is related to financial support. This discipline teaches how the entrepreneurs can finance their new business, and what mechanisms they have to get subvention money from government innovation agency, such as FINEP. At the same time, it is important to mention that this activity is optative for all courses, it is not mandatory for students in their curricula. They take this only if they are interested in learning financial issues. Even though, the number of students is increasing from 2011 to 2015.

Figure 6 - Students Attendance in Activity 3 - 2011 - 2015

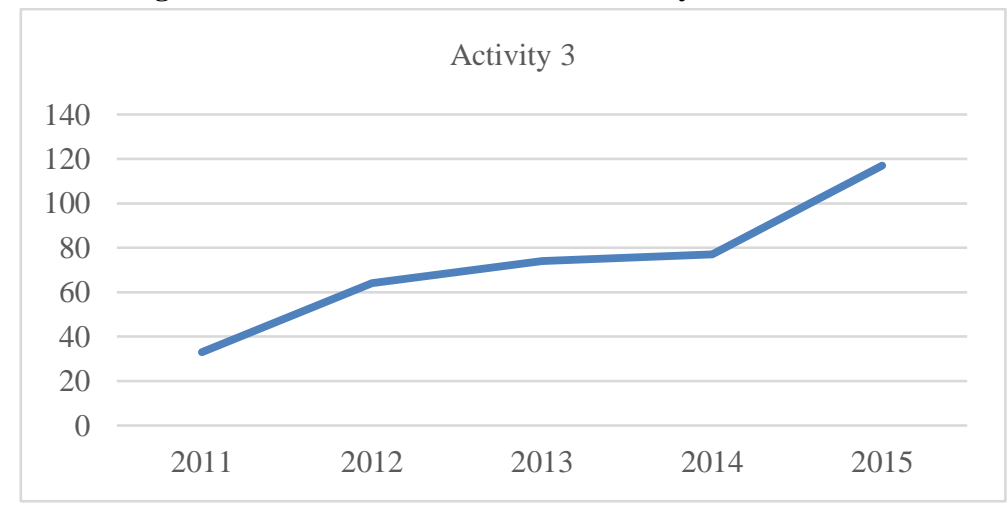

Source: Unisinos academic register, 2016

\subsection{ENTREPRENEURSHIP AND INNOVATION MANAGEMENT}

After 5 years of the three disciplines, the Undergratuation University council realize that an important part of the whole subject was missing, which was how to manage the new business. Normally young people do not have experience in management and they need at least a minimal orientation for that.

Thus, from 2015 a new activity was offer, regarding entrepreneurship and innovation management. In the first year, 256 students attended this discipline, as it is possible to see at table 1 . The contents of this activity are centered on the concept and characteristics of the National Innovation System. In Brazil, NSI is not so well organize, and entrepreneurs need to know where they can find support or even fund capital for their projects. Due to that, the subject of this activity covers innovation in the national environment and their public agencies such as FINEP (Financiadora de Estudos e Projetos) and SEBRAE (Serviço Brasileiro de Apoio as Micro e Pequenas Emrpesas). Those public 
organizations offer funding to innovative projects and SEBRAE offer support in terms of management and market research too.

Additionally, in this activity, students will have contact with private organizations in order to know how to deal with trade unions, incubators, accelerators, technology parks and venture or angel investors. Those actors are relevant for a student who planning to become an entrepreneur. At least he will have the knowledge where he can find solutions for his future business.

At the same time, throughout this activity, students will have contact with the mechanisms of entrepreneurship and innovation fostering in Brazil, as for example the regulatory frameworks and tax incentives. Finally, students will study entrepreneurship and innovation management into organizations; tools to innovate in business models, such as lean start-up and Fundraising Projects.

\subsection{COMPLEMENTARY ACTIVITIES}

Additionally to those four academic activities described above, Unisinos Entrepreneurship and Innovation Hub prepares some complementary activities to enhance students to become entrepreneurs, such as connections with Tecnosinos Tech Park, Talent Program, Roser Award and Warm up workshop.

\subsubsection{Relations and connections between University entrepreneurship education and Tecnosinos Tech Park}

Another important activity in which students are involved is the Tecnosinos Tech Park visits. Tecnosinos is the São Leopoldo Tech Park located adjacent to Unisinos University Campus. It is an especial tool of socio economic development and has a role to promote the proper creation environment, development and generation of value through the establishment of technology based companies. São Leopoldo is part of high-tech cluster economy in Rio Grande do Sul state, located at the Vale dos Sinos region, $30 \mathrm{~km}$ distant from the state capital, Porto Alegre. With 210 thousands inhabitants, São Leopoldo is the German immigration cradle.

This program started in 2012, and from that year until 2015, more than two thousand students have visited Tecnosinos, as it is shown on figure 6 . This program consists in three parts. First, students have an overview presentation of the Park. Secondly, two or three entrepreneurs deliver a testimony of their experience on becoming an entrepreneur and how are they managing their current business.

At last, the students visit some companies inside the Park. The feedback that the Park administration receive from the students have been very fruitful and shows that this has been the right way to incentive them on the possibility of entrepreneurship. 
Figure 6 - Number of Students visiting Tecnosinos - 2012 to 2015.

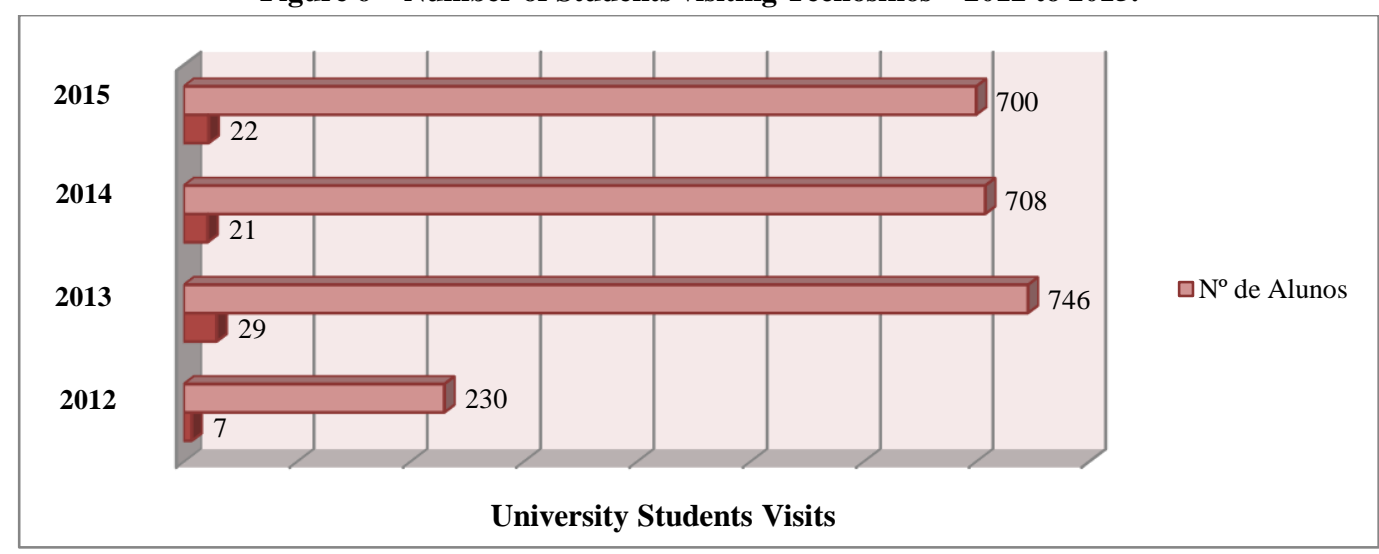

Source: Unitec/Tecnosinos register, 2016

\subsubsection{Talent Program}

This program is unique in all Tech Parks in Brazil. Tecnosinos has more than 30 high schools, mainly in the Sinos Valley region, that signed an agreement in order to take their students to visit Tecnosinos in a regular basis. This initiative is very important mainly because these students, after finishing high school, become Unisinos students and they already have information about the Tech Park and its opportunities.

The Talent Program is considered a small seed for youth generation in order to see other options than becoming an employee in a big company. They have the opportunity of thinking about having their own business. From the early stage of their life, they can have a new vision. A vision is a dream, and maybe this program is setting a dream in their young minds.

From 2011 to 2015, a surprising number of high school students have been visiting Tecnosinos, as it is possible to see on figure 7. This program works in the same dynamics as the one with University students, described above. The final impression and feedback of the students are an excellent motivation to continue with this program. Tecnosinos staff spend a lot of energy to set it up and make it works, but there is a large compensation in terms of spreading the entrepreneurship spirit over the young generation.

Figure 7 - Number of Middle School Students visiting Tecnosinos - 2011 to 2015.

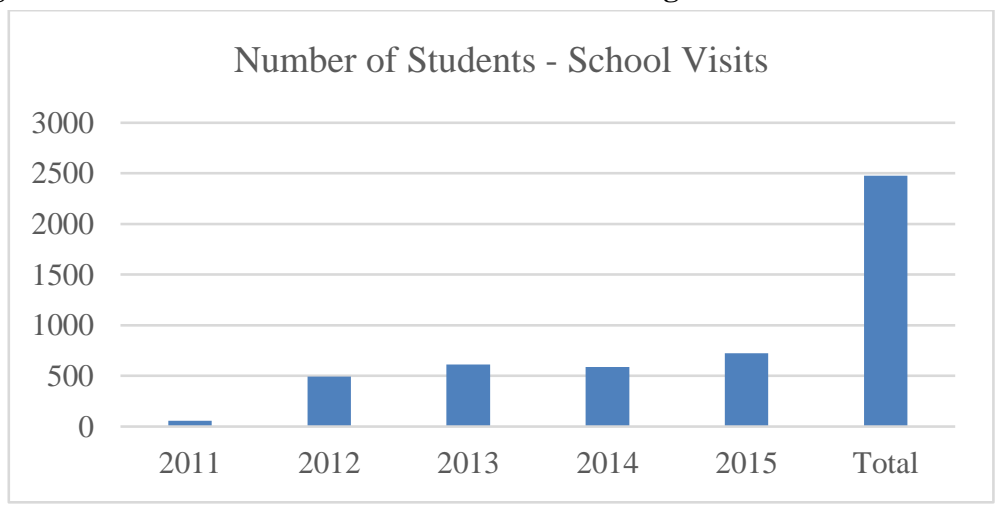

Source: Unitec/Tecnosinos register, 2016

\subsubsection{Roser Award}

Roser Award is an initiative promoted by Tecnosinos Tech Park in partnership with Unisinos University (I \& E HUB) to foster social entrepreneurship through the intensive use of technology. Roser 
Award goes beyond analyzing and rewarding good ideas. It is a unique opportunity of pivoting projects where all participants benefit of its acceleration model.

The format of the activity has being evolving since its first edition in 2012. On the last edition in 2015, Roser Award had 58 projects participating in a 24 hours marathon. During this $24 \mathrm{~h}$, all the teams went through an acceleration process of their business, from workshops on how to build a business model to how to pitch to investors, and many other activities. Accelarator Ventiur, partner of Tecnosinos and Unitec incubator on this project, was responsible for conducting the activities. All the teams had to go on field, test and validate the projects and do adjustments upon return. The professors from the Unisinos Entrepreneurship and Innovation Hub took part during the entire event to support the team as well as mentors like entrepreneurs that have their business incubated at the park.

The first impact is the number of companies focused on social entrepreneurship present in the business incubator. From the 25 companies incubated today, 6 of them works on projects with social impact and 5 of them came from the Roser Award initiative. This is a very important number for the incubator, as before the award, the proportion of projects with social impact was $10 \%$ or less.

The other impact is definitely caused by the winners' solutions. In 2014, the winning startup called Silo Verde, developed a silo for storage of seeds and grains for small farmers. It is estimated that in Brazil there are about 5 million establishments with up to 100 hectares and potential users of the solution developed by Silo Verde. We are talking about Brazil now, but this is a solution that can solve seed storage problems for small farmers globally.

In 2015, the winner was Vital and the solution developed was a method of obtaining the active ingredient of the liquid preservative of human organs used in transplants. It is estimated that this method of production represents a $40 \%$ savings in the final cost of the product. Brazil imports this product since there is no domestic production. Brazil has currently about 60,000 people on the waiting list for transplants, but $70 \%$ of the organs that could be transplanted are lost for several reasons. Regarding the solution developed by Vital, losses of $24 \%$ for storage and transport could be avoided.

In other words, the winners of the Roser Award can become high-impact entrepreneurs in solving global problems. This is an enough reason to believe in this initiative and promote it in order to make the replication possible.

\subsubsection{Warm up}

Warm up is an activity that Tecnosinos runs together in partnership with Ventiur Accelerator. This program consist in to open opportunities for entrepreneurs to test their projects or ideas in order to have a final and big picture if their project can become a new startup.

The program is divided in five workshops, covering operational, product definition, market research and testing, financial issues and a pitch to angel investors. The first edition was in 2015 and Tecnosinos received 65 projects. From those, 23 were selected, 5 achieved the final stage and had the opportunity to pitch to angel investors. One of them was selected as an incubated startup invested by angel capital, as it is possible to see on figure 8 . 
Figure 8 - Warm up process - 2015.

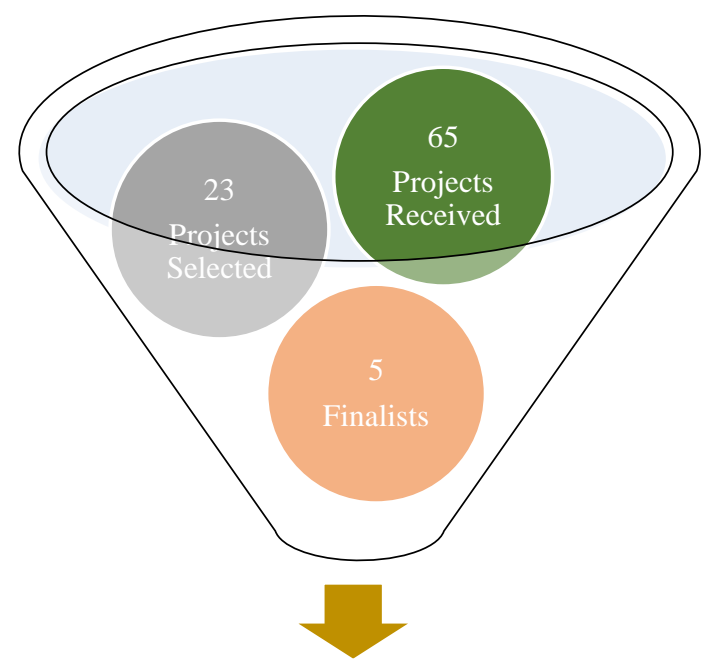

1 incubation

Source: Unitec/Tecnosinos register, 2016

\section{RESULTS}

A good example of the whole initiative impact in both sides, students and the tech park, is the startup Tridel Technology Solutions. The startup idea begun during the Organizational Entrepreneurship and Innovation class activities. The partners received the task of building a company from an idea and working on a business plan for it. They worked on the idea of an instant cooler for drinks, capable of freezing in just 1 minute, with a small ice portion, a can of soda. Nowadays, Tridel is incubated at Unitec and closed 2015 with U\$265,000.00 revenues.

As Tridle example, there are several other new startups, which are incubated in Unitec/Tecnosinos that are coming from those programs described in this paper, such as Silo Verde, Vital, Medida Saúde, Bee Touch, Revofoot, Smartronic and Menvia.

Additionally, as a relevant result of the E \& I HUB, over 5 thousand students have taken entrepreneurship and innovation classes, from 2011 to 2015, considering that activities 2 is taken by the same students from Activity 1, as it is shown on table 1. This important achievement brings other consequences. Unisinos receives students from all regions of Rio Grande do Sul state, even from other Brazilian states. Therefore, these activities have the possibility to spread the entrepreneurship, not only in the Sinos Valley region, but also to other regions. The number of students have been increasing year by year, as it is possible to see on figure 9 .

Table 1 - Number of students of E \& I HUB - by activity - 2011 - 2015

\begin{tabular}{ccccc}
\hline & Activity 1 & Activity 2 & Activity 3 & Activity 4 \\
\hline 2011 & 661 & 528 & 33 & \\
2012 & 840 & 585 & 64 & \\
2013 & 1089 & 957 & 74 & \\
2014 & 1094 & 1039 & 77 & 256 \\
2015 & 1298 & 1395 & 117 & $\mathbf{2 5 6}$ \\
\hline Total & $\mathbf{4 9 8 2}$ & $\mathbf{4 5 0 4}$ & $\mathbf{3 6 5}$ & \\
\hline
\end{tabular}

Source: Unisinos academic register, 2016 
Figure 9 - Number of students of E \& I HUB, by activity, 2011 - 2015 - in a graphic

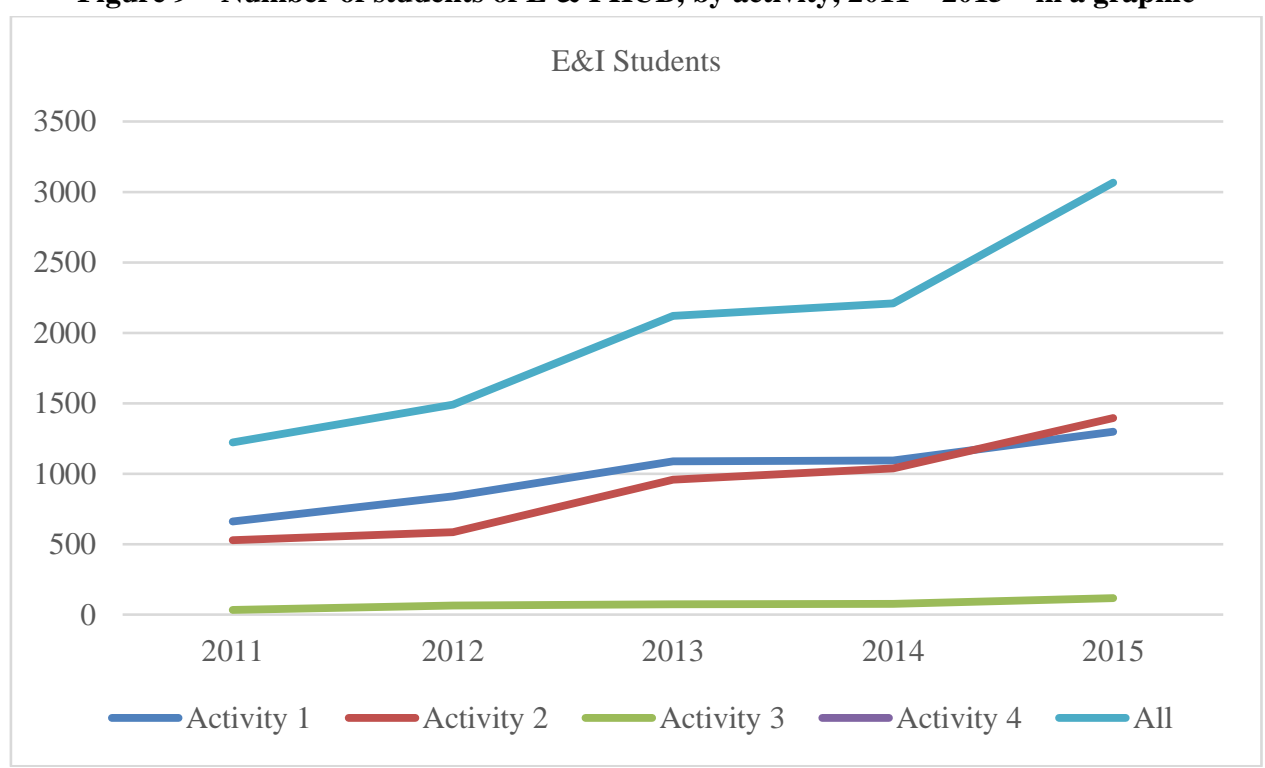

Source: Unisinos academic register, 2016

The figures of all Entrepreneurship and Innovation Hub activities show that there is a lot of effort to develop and continuously to maintain them in function. Unisinos professors and Unitec/Tecnosinos team have to spend time and hard work. Most important than that is the result in the Tecnosinos innovation ecosystem.

\section{FINAL CONSIDERATIONS}

Unisinos Entrepreneurship and Innovation Hub has been a successful initiative in order to plant a seed of new ideas in the students mind set. As it was possible to realize through the figures shown in this paper, many Unisinos University students got the chance to have classes regarding this subject. They were participants in four different academic activities, additionally with complementary activities related to Tecnosinos Tech Park.

Other important point to be considered is that from the cultural approach, the existing inhabitants in the Region come out from mixed and multicultural races and the entrepreneurial spirit is not the main characteristics of them. There are some examples of how entrepreneurs were fundamental for development such as in U.S., Europe and Asian countries. At the same time, the Latin American people, in its majority, is not risk-taken driven to venture their capital in a new business. At the same time, schools and Universities education must take the front to improve the entrepreneurship education as a strong part of their strategy. That's why improving programs like the E \& I HUB is a key issue to develop a region, even a country.

The main objective of the Park is to promote the proper environment for the creation, development and generation of value through the establishment of technology-based companies, in order to influence positively Brazilian social and economic development and especially the local community where the park is located. The E \& I HUB is not only aligned with the mission of the park, but it is a fundamental program that also supports the park growth strategy, capacitating labor force to work at the park companies and fostering the birth of new startups. 


\section{REFERENCES}

ALBUQUERQUE, E. M. Sistema nacional de inovação no Brasil: uma análise introdutória a partir de dados disponíveis sobre ciência e tecnologia. IN: Revista de Economia Política, vol. 16, no. 3 (63). Rio de Janeiro: Nobel, julho-setembro 1996.

DAHLMAN, C. J.; FRISCHTAK, C. R., National Systems Supporting Technical Advance in Industry: The Brazilian Experience. IN: National Innovation Systems - A Comparative Analysis, p. 414 450. New York, Oxford University Press, 1993.

CHANT, S. Urban livelihoods, employment and gender. IN: Latin America Transformed Globalization and Modernity. Edited by GWYNNE, Robert N \& KAY, Cristóbal. $2^{\text {nd }}$. Edition. 2004, p. $210-231$.

DEGEN, R. J. Empreendedor - empreender como opção de carreira. Pearson. 2009.

DUTRÉNIT, G. Sistema Nacional de Innovacion. IN: Revista de Comercio Exterior Del Banco Nacional de Comercio Exterior, Vol. 44, número 8, p. 666-668. México, agosto/1994.

GWYNNE, R. N.; KAY, C. Latin America Transformed - Globalization and Modernity. Second Edition, Hodder Arnold Editors, New York, U.S., 2004.

HOBSBAWM, E. The Age of Revolution 1789-1848. Vintage Books, 1996.

KURATKO, D.F.; HODGETTS, R.M. Entrepreneurship: Theory, process, practice. Mason, OH: South-Western College Publishers, 2004.

LIMA, E.; LOPES, R. M.; NASSIF, V.; DA SILVA, D. Opportunities to Improve Entrepreneurship Education: Contributions Considering Brazilian Challenges. IN: Journal of Small Business Management, 2015 53(4), p. 1033-1051.

LONGMAN - Dictionary of Contemprary English - New Edition. Pearson Education Limited Ed.Harlow - England, 2003.

OECD - ORGANIZATION FOR ECONOMIC CO-OPERATION AND DEVELOPMENT. Manual de Oslo - proposta de diretrizes para coleta e interpretação de dados sobre inovação tecnológica, 1997. Traduzido pela FINEP, 2004.

OECD - ORGANIZATION FOR ECONOMIC CO-OPERATION AND DEVELOPMENT.

Dynamising National Innovations Systems. Paris: OECD publications, 2002.

OLIVEIRA, D. de P. R. de. Empreendedorismo - Vocação, Capacitação e Atuação direcionadas para o plano de negócios. São Paulo: Atlas, 2014.

PEREZ, C. Tecnological change and opportunities for development as a moving target. CEPAL REVIEW 75 - p. 109-130 - December/2001.

PRODANOV, C. C; FREITAS, E. C. de. Metodologia do Trabalho Científico: Métodos e Técnicas da Pesquisa e do Trabalho Científico. 2ª ${ }^{\text {a }}$ Ed. E-Book. Novo Hamburgo. Ed. Feevale, 2013.

RIDEOUT, E. C.; GRAY, D. O. Does Entrepreneurship Education Really Work? A Review and Methodological Critique of the Empirical Literature on the Effects of University-Based Entrepreneurship Education. IN: Journal of Small Business Management 2013 51(3), p. 329-351 
SALA-I-MARTIN, X.; BRANKE, J.; HANOUZ, M. D.; GEIGER, T.; MIA, I. The Global Competitiveness Index 2010-2011: Looking Beyond the Global Economic Crisis. IN: The Global Ecompetitiveness Report 2010-2011. Edited by Professor Klaus Schwab. WORLD ECONOMIC FORUM, Geneva, Switzerland 2010.

SANCHEZ, J.C. The Impact of an Entrepreneurship Education Program on Entrepreneurial Competencies and Intention.; IN: Journal of Small Business Management 2013 51(3), p. 447-465

SILVA, Patricio. The new political order: towards technocratic democracies? IN: Latin America Transformed - Globalization and Modernity. Edited by GWYNNE, R. N; KAY, C. $2^{\text {nd }}$. Edition. 2004, p. 157-170.

SCHUMPETER, J. A (1942). Capitalism, Socialism and Democracy. Harperperennial Modernthought, 1975.

UNISINOS - University do Vale do Rio dos Sinos. Register database. São Leopoldo, 2016.

UNITEC/UNISINOS - Unidade de Inovação e Tecnologia da Unisinos. Register database. São Leopoldo, 2016. 